ISSN 0258-7122

Bangladesh J. Agril. Res. 38(3): 455-466, September 2013

\title{
FARM LEVEL POTATO (Solanum tuberosum L.) CULTIVATION IN SOME SELECTED SITES OF BANGLADESH
}

\author{
S. M. SHAHRIAR ${ }^{1}$, M. KAMRUL HASAN ${ }^{2}$ AND M. KAMRUZZAMAN $^{3}$
}

\begin{abstract}
The study was carried out in two intensive potato growing areas (Rangpur and Munshigonj) to estimate the technical efficiency of potato producers and to describe the level of variation in potato productivity due to differences in input use. Data were collected from 60 farmers (30 farmers from each district) using simple random sampling technique. Average technical efficiency was $86 \%$ implying that on average $14 \%$ inefficiency remained at producers' level. The application of human labour, MoP, and weedicides would increase potato yield significantly. On the other hand, the coefficient of urea and pesticide cost was found negative and significant which advarsely effect the yield of potato. Moreover, the coefficient of operated land and extension linkage were found negative and significant implying that with further increase in operated land and extension linkage, technical efficiency would increase. Munshigonj was found to be more suitable area for potato production. The performance of selfproduced and stored potato seeds are poor compared to the seeds from BADC. Supply of quality seeds to the farmers should be ensured by strengthening seed production and distribution system both in public and private sectors.
\end{abstract}

Keywords: Potato cultivation, technical efficiency, Rangpur, Munshigonj

\section{Introduction}

Potato is one of the most important crops in Bangladesh. It is the third largest food crop grown in Bangladesh and mainly consumed as vegetable. Potato is also the leading vegetable crop in the world. During last 30 years from 1981-82 to $2010-11$, the annual growth rate of area was $16.34 \%$. The expansion of production over the same period was $12.11 \%$ and yield was increasing at a very high rate of $42.53 \%$ annually (Table 1 ).

Table 1. Growth rate of area, production and yield of potato during last 30 years (1981-82 to 2010-11) in Bangladesh.

\begin{tabular}{lcccc}
\hline Items & Area (000 ha) & Production (000 ton) & Yield (t/ha) \\
\hline Mean & 206.77 & 2770.02 & 12.17 \\
Growth rate (\%) & 16.34 & 12.11 & 42.53 \\
$\mathrm{R}^{2}$ & 0.89 & 0.89 & 0.81 \\
\hline
\end{tabular}

Note: Growth rates were calculated by fitting an OLS semi-log function Source: BBS (1994, 2002, 2005, 2011).

${ }^{1}$ Scientific Officer (IAPP Project), Bangladesh Rice Research Institute (BRRI), Rangpur; ${ }^{2}$ Principal Scientific Officer, Planning and Evaluation Division, Bangladesh Agricultural Research Institute (BARI), Gazipur-1701, ${ }^{3}$ Professor, Dept. of Agricultural Economics, Bangabandhu Sheikh Mujibur Rahman Agricultural University (BSMRAU), Gazipur1701, Bangladesh. 
Due to the introduction and adoption of high yielding variety (HYV) and production technology of potato, the area, production, and yield of the crop sharply increased after 1990s. Still now the area, production, and yield of potato are in increasing trend (BBS, 1994; BBS, 2011). During 1990-91, potato was cultivated in 0.124 million hectare in Bangladesh which produced 1.237 million MT fresh potatoes. The area increased to 0.46 million hectare' and production enlarged to 8.33 million MT in 2010-11 (BBS, 2011). Yield of potato was also doubled during this period showing an enlargement from $9.99 \mathrm{t} / \mathrm{ha}$ to $18.09 \mathrm{t} / \mathrm{ha}$.

It is necessary to produce more vegetables per unit of land using existing technology because cultivated land is very limited and farm resources are utilized in a less efficient way. Producer's efficiency has long been an area of interest in the investigation of farm operation. Farmers' production performance does not depend only on physical resources and technology available to them, but also on existing farm management conditions. Studies examining farming efficiency in developing countries show production efficiency levels ranging from 60 to 82 percent irrespective of crop types and regions (Rahman, 2003; Coelli et al., 2002; Wang et al., 1996). The efficient use of resources is an important indicator of increased production in agriculture. Efficient use of inputs can help farmers to get higher production from a given amount of resources. Several studies in other countries have shown that there is significant potential for raising agricultural output and profitability as well by improving productive (technical and allocative) efficiency using existing resources (Rahman, 2002). The present study is, therefore, an attempt to analyze the farm level potato cultivation in the sample study areas.

The specific objectives of the study were as follows:

i) to describe the level of variation in potato productivity due to differences in input use at farm level.

ii) to delineate the technical efficiency of potato farmers in the sample areas, and

ii) to understand the factors affecting inefficiency of potato producers.

\section{Methodology}

\section{Study area and sampling}

The present study was conducted in two purposively selected potato growing districts of Bangladesh. Munshiganj was chosen as high concentrated area and Rangpur as moderate concentrated area for potato production.

Sadar upazillas under each district were selected purposively. Among the 11 unions of Rangpur Sadar and 10 unions of Munshigonj Sadar Upazilla, Chandanpat union of Rangpur and Adhara union of Munshigonj Upazila were 
selected randomly. In the next step, three villages from each of the unions were also selected randomly. The villages under Chandanpat union were Shabajpur, Laherirhat, Islampur and that from Adhara union were Deyankandhi, Sonali, and Charkishorgonj. A list of potato farmers of the selected villages was prepared with the help of village leaders and field level extension personnel. Then farmers were selected using simple random sampling technique. Considering the limitation of time and fund, sample size of potato farmers was fixed at 60 (taking 10 farmers from each village). Data were collected during April-May 2010. Pretesting was done before finalizing the interview schedule. Secondary data on area and production of potato were also used to supplement the information.

\section{Analytical Techniques}

\section{Technical efficiency estimation}

Cobb-Douglas stochastic frontier production function was employed to estimate technical efficiency of the potato growers. It is the most widely used form for fitting agricultural production data because of its mathematical properties, ease of interpretation and computational simplicity (Heady and Dillon, 1969). It is a homogeneous function that provides a scale factor enabling one to measure the return to scale and to interpret the elasticity coefficients with relative ease. It is also relatively easy to estimate because in logarithmic form it is linear and parsimonious (Beattie and Taylor, 1985). Thus, Cobb-Douglas specification provides an adequate representation of the agricultural production technology.

The empirical Cobb-Douglas frontier production function with double log form can be expressed as:

$$
\begin{aligned}
\operatorname{LnY}_{i}= & \beta_{0}+\beta_{1} \operatorname{LnX}_{1 \mathrm{i}}+\beta_{2} \operatorname{LnX}_{2 \mathrm{i}}+\beta_{3} \operatorname{LnX} X_{3 \mathrm{i}}+\beta_{4} \operatorname{LnX}_{4 \mathrm{i}}+\beta_{5} \operatorname{LnX} X_{5 \mathrm{i}}+\beta_{6} \operatorname{LnX}_{6 \mathrm{i}}+ \\
& \beta_{7} \operatorname{LnX}_{7 \mathrm{i}}+\beta_{8} \operatorname{LnX} X_{8 \mathrm{i}}+\beta_{9} \operatorname{LnX} \mathrm{X}_{9 \mathrm{i}}+\beta_{10} \operatorname{LnX}_{10 \mathrm{i}}+\beta_{11} \operatorname{LnX}_{11 \mathrm{i}}+\beta_{12} \operatorname{LnX}_{12 \mathrm{i}}+ \\
& \eta_{1} \mathrm{D}_{1 \mathrm{i}}+\eta_{2} \mathrm{D}_{2 \mathrm{i}}+\eta_{3} \mathrm{D}_{3 \mathrm{i}}+\mathrm{v}_{\mathrm{i}} \mathrm{u}_{\mathrm{i}}
\end{aligned}
$$

Where,

$\mathrm{Ln}=$ Natural logarithm,

$Y_{i}=$ Yield of potato of the $\mathrm{i}$-th farm $(\mathrm{kg} / \mathrm{ha})$

$X_{1 i}=$ Human labour used by the i-th farm (man-days/ha)

$X_{2 i}=$ Mechanical power cost of the i-th farm (Tk/ha)

$X_{3 i}=$ Seed used by the i-th farm ( $\left.\mathrm{kg} / \mathrm{ha}\right)$

$X_{4 i}=$ Urea used by the $\mathrm{i}$-th farm ( $\left.\mathrm{kg} / \mathrm{ha}\right)$

$X_{5 i}=$ TSP used by the i-th farm ( $\left.\mathrm{kg} / \mathrm{ha}\right)$

$X_{6 i}=$ MoP used by the $\mathrm{i}$-th farm ( $\left.\mathrm{kg} / \mathrm{ha}\right)$ 
$X_{7 i}=$ Zinc sulphate used by the $\mathrm{i}$-th farm ( $\left.\mathrm{kg} / \mathrm{ha}\right)$

$X_{8 i}=$ Boric acid used by the $\mathrm{i}$-th farm ( $\left.\mathrm{kg} / \mathrm{ha}\right)$

$X_{9 i}=$ Farm yard manure used by the i-th farm $(\mathrm{kg} / \mathrm{ha})$

$X_{10 i}=$ Weedicide cost of the i-th farm (Tk/ha)

$X_{11 i}=$ Pesticides cost of the i-th farm (Tk/ha)

$X_{12 i}=$ Irrigation cost of the i-th farm (Tk/ha)

$D_{1 i}=$ Dummy for soil type of the i-th farm (1=Loamy soil, $0=$ otherwise)

$D_{2 i}=$ Dummy for seed source of the i-th farm ( $1=$ Own seed, $0=$ otherwise)

$D_{3 i}=$ Dummy for location (1=Rangpur, $0=$ otherwise)

$\beta^{\prime} s$ and $\eta^{\prime} s$ are unknown parameters to be estimated

$v_{i}-u_{i}=$ error term

$\mathrm{V}_{\mathrm{i}}$ 's were assumed to be independently and identically distributed (iid) random errors, having $\mathrm{N}\left(0, \sigma_{v}^{2}\right)$ distribution.

\section{Technical inefficiency effect model}

The $u_{i}$ 's were non-negative random variables, assumed to be independently distributed such that the technical inefficiency effect for the $\mathrm{i}^{\text {th }}$ farmer, $u_{i}$, were obtained by truncation of normal distribution with mean zero and variance, $\sigma_{u}^{2}$, such that

$\mathrm{u}_{\mathrm{i}=} \delta_{0}+\delta_{1} \mathrm{z}_{1 \mathrm{i}}+\delta_{2} \mathrm{z}_{2 \mathrm{i}}+\delta_{3} \mathrm{z}_{3 \mathrm{i}}+\delta_{4} \mathrm{z}_{4 \mathrm{i}}+\delta_{5} \mathrm{z}_{5 \mathrm{i}}+\delta_{6} \mathrm{z}_{6 \mathrm{i}}+\mathrm{W}_{\mathrm{i}}$

where,

$z_{1 i}=$ Operated land of the i-th farm operator (ha)

$z_{2 i}=$ Farming experience of the $\mathrm{i}$-th farm operator (years)

$z_{3 i}=$ Level of education of the $\mathrm{i}$-th farm operator (year of schooling)

$z_{4 i}=$ Family size of the $\mathrm{i}$-th farm operator (number)

$z_{5 i}=$ Dummy for extension linkage of the $\mathrm{i}$-th farm operator (1=yes, $0=$ otherwise)

$z_{6 i}=$ Dummy for potato training of the $\mathrm{i}$-th farm operator ( $1=\mathrm{yes}, 0=$ otherwise)

$\delta$ 's are unknown parameters to be estimated

$W_{i}$ s were unobservable random variables or classical disturbance term, which are assumed to be independently distributed, obtained by truncation of the normal distribution with mean zero and unknown variance, $\sigma^{2}$, such that $u_{i}$ is nonnegative. 
The $\beta, \eta$, and $\delta$ coefficients are to be estimated with the variance parameters which are expressed in terms of

$$
\sigma^{2}=\sigma_{u}^{2}+\sigma_{v}^{2}
$$

and $\quad \gamma=\sigma_{u}^{2} / \sigma^{2}$

$\gamma$ is the ratio of variance of farm specific technical efficiency to the total variance of output and has a value between zero and one.

The estimates for all parameters of the stochastic frontier and inefficiency model were estimated in a single stage by applying econometric computer software package FRONTIER 4.1 (Coelli, 1996).

\section{Results and Discussion}

\section{Yield of potato according to soil type and farm size}

Farmers who cultivated potato on loamy soil for potato production got comparatively high yield ( $26083 \mathrm{~kg} / \mathrm{ha}$ ) in both the locations (Table 2) implying that loamy soil is suitable for potato production. It was also observed that the average yield of potato varied considerably among the farm category between the locations. The highest level of yield was obtained by large farms and lowest was at small farms in both locations. This may be due to the fact that large farmers used more inputs in potato production compared to small farms.

Table 2. Variations in potato yield according to soil type and farm size in the study areas, 2010.

\begin{tabular}{l|ccc|c|c|c|c|}
\hline \multirow{2}{*}{ Location } & \multicolumn{5}{|c|}{ Yield (kg/ha) of potato according to } & \multirow{3}{*}{ All } \\
\cline { 2 - 7 } & \multicolumn{3}{|c}{ Soil type } & \multicolumn{3}{c}{ Farm size } & \\
\cline { 2 - 7 } & Sandy loam & Loamy & Silty loam & Small & Medium & Large & \\
\hline Rangpur & 22212 & 22766 & 21568 & 21449 & 22136 & 22961 & 22182 \\
Munshigonj & 27666 & 28790 & 26430 & 26416 & 27598 & 28817 & 27610 \\
All & $\mathbf{2 4 6 4 5}$ & $\mathbf{2 6 0 8 3}$ & $\mathbf{2 4 0 4 8}$ & $\mathbf{2 3 7 2 5}$ & $\mathbf{2 4 8 6 7}$ & $\mathbf{2 6 3 7 7}$ & $\mathbf{2 4 8 9 6}$ \\
\hline
\end{tabular}

Source: Field survey (2010)

\section{Yield of potato according to seed source}

Yield of potato was found higher with seeds from BADC $(25667 \mathrm{~kg} / \mathrm{ha})$ compared to other sources (Table 3). In both the locations, potato yield was higher for the farmers those used seeds from BADC. Farmers who used their own seeds obtained lower yield ( $24205 \mathrm{~kg} / \mathrm{ha})$. This may be due to lack of knowledge regarding seed production and preservation by the farmers. 
Table 3. Yield of potato according to seed sources in the study areas, 2010.

\begin{tabular}{l|c|c|c|c|c}
\hline \multirow{2}{*}{ Location } & \multicolumn{5}{c}{ Yield (kg/ha) } \\
\cline { 2 - 6 } & Own & Local market & Neighbors & BADC & All \\
\hline Rangpur & 21432 & 22156 & 22523 & 22617 & 22182 \\
Munshigonj & 26701 & 28009 & 27556 & 28175 & 27610 \\
All & $\mathbf{2 4 2 0 5}$ & $\mathbf{2 4 3 5 1}$ & $\mathbf{2 4 5 3 6}$ & $\mathbf{2 5 6 6 7}$ & $\mathbf{2 4 8 9 6}$ \\
\hline
\end{tabular}

Source: Field survey (2010)

\section{Yield of potato according to use of urea and MoP fertilizer}

All the farmers applied high dose of fertilizers than the recommended dose. The farmers of Munshiganj applied 3-4 times higher dose of N, P and K fertilizer than the recommended dose in the potato field (Choudhury et al., 2006).

Table 4. Variation in potato yield according to use of urea fertilizer at farmers' field.

\begin{tabular}{l|ccccc}
\hline \multirow{2}{*}{ Location } & \multicolumn{4}{|c}{ Yield (kg/ha) as per urea use (kg/ha) } \\
\cline { 2 - 5 } & $150-300$ & $301-450$ & $451-600$ & $601-750$ \\
\hline Rangpur & 23261 & 21103 & - & - \\
Munshigonj & - & - & 27900 & 27320 \\
All & $\mathbf{2 3 2 6 1}$ & $\mathbf{2 1 1 0 3}$ & $\mathbf{2 7 9 0 0}$ & $\mathbf{2 7 3 2 0}$ \\
\hline
\end{tabular}

Source: Field survey (2010)

Farmers believed that higher dose of fertilizers would increase yield significantly. But the previous studies showed that the higher rate of fertilizers that applied by the farmers increased potato yield with a non-significant way (Choudhury et al., 2006). It appears in Table 4 that application of urea close to recommend dose gave higher yield. Similar result also appears in Table 5 for the distribution of MoP fertilizer.

Table 5. Variation in potato yield according to use of MoP fertilizer.

\begin{tabular}{l|ccccc}
\hline \multirow{2}{*}{ Location } & \multicolumn{4}{|c}{ Yield $(\mathrm{kg} / \mathrm{ha}$ ) as per MoP use (kg/ha) } \\
\cline { 2 - 5 } & $100-200$ & $201-300$ & $426-550$ & $551-675$ \\
\hline Rangpur & 21893 & 22471 & - & - \\
Munshigonj & - & - & 28140 & 27080 \\
All & $\mathbf{2 1 8 9 3}$ & $\mathbf{2 2 4 7 1}$ & $\mathbf{2 8 1 4 0}$ & $\mathbf{2 7 0 8 0}$ \\
\hline
\end{tabular}

Source: Field survey (2010)

Maximum likelihood estimates of the frontier production function and technical inefficiency model for potato

To generate farm specific technical efficiency indices for potato production in the study areas, the stochastic frontier production function with yield as dependent 
variable was estimated in which all variables were standardized on the basis of per hectare of land area. The ML estimates of the coefficients of stochastic CobbDouglas production frontier and technical inefficiency model which show the best practice performance, i.e., efficient use of the available technology are presented in Table 6 .

The empirical results indicated that the coefficients of human labour, MoP, weedicide cost, and dummy for soil type were positive and significant. It indicated that human labour, MoP, weedicide cost, and use of loamy soil had significant and positive influence on potato production. On the other hand, coefficients of urea, pesticide cost and dummy for seed source had negative effect on potato production.

At $1 \%$ level of significance, the coefficients of human labour (0.169) was positive and significant implying that holding other things constant, the yield of potato would increase by 0.17 percent if farmers would use $1 \%$ additional human labour. The coefficient of MoP (0.16) and weedicide cost (0.08) were positive and significant at $10 \%$ level implying that holding other things constant, the yield of potato would increase by 0.16 and 0.08 percent if the farmers would apply $1 \%$ additional quantity of MoP and $1 \%$ additional cost of weedicide. The value of production coefficient of urea was -0.33 , which was significant at $1 \%$ level of probability. The negative value indicates the excess use of urea fertilizer. This implied that 1 percent decrease in urea application resulted in 0.33 increase in yield of potato, keeping other things remain constant.

The coefficient of the dummy for soil type (0.08) was positive and significant at $1 \%$ level, while the coefficients of dummy for location (0.94) and seed source (0.04) were negatively significant implying that yield of potato would increase if loamy soil lands were brought under potato cultivation. This also indicated that farmers of Rangpur area obtained lower yield compared to farmers of Munshigonj area. The negative and significant value of the coefficient of seed source implying that yield of potato would be increase if farmers decrease use of self produced seeds. In other words, farmers could increase their yield by increased use of potato seeds from BADC, neighbours or local market.

\section{Factors affecting technical inefficiency for potato producer}

The coefficient of operated land was -0.098 in the inefficiency model, which was significant at $1 \%$ level (Table 6). This indicated that technical inefficiency of the potato growers would decrease with the increase in farm size.

The coefficient of extension linkage was -0.093 , which was significant at $1 \%$ level. This indicated that technical inefficiency decrease with the increase in extension linkage. On the other hand, the estimated coefficients of farming experience, farmers' education, family size and training had shown no effect on the technical inefficiency of the potato growers. 
Table 6. Maximum likelihood estimates of the stochastic Cobb-Douglas frontier production function and technical inefficiency model for potato.

\begin{tabular}{|c|c|c|c|c|}
\hline Independent variables & Parameters & Co-efficient & $\begin{array}{l}\text { Standard } \\
\text { error }\end{array}$ & t-ratio \\
\hline \multicolumn{5}{|l|}{ Stochastic frontier } \\
\hline Constant & $\beta_{0}$ & 6.910 & 0.986 & 7.01 \\
\hline Human labour $\left(\mathrm{X}_{1}\right)$ & $\beta_{1}$ & $0.169 * * *$ & 0.043 & 3.93 \\
\hline Mechanical cost $\left(\mathrm{X}_{2}\right)$ & $\beta_{2}$ & -0.315 & 0.201 & -1.57 \\
\hline Seed $\left(X_{3}\right)$ & $\beta_{3}$ & 0.196 & 0.1601 & 1.23 \\
\hline Urea $\left(\mathrm{X}_{4}\right)$ & $\beta_{4}$ & $-0.327 * * *$ & 0.126 & -2.59 \\
\hline $\operatorname{TSP}\left(\mathrm{X}_{5}\right)$ & $\beta_{5}$ & -0.059 & 0.101 & -0.59 \\
\hline $\operatorname{MOP}\left(\mathrm{X}_{6}\right)$ & $\beta_{6}$ & $0.156^{*}$ & 0.093 & 1.67 \\
\hline Zinc sulphate $\left(X_{7}\right)$ & $\beta_{7}$ & 0.012 & 0.022 & 0.53 \\
\hline Boric acid $\left(\mathrm{X}_{8}\right)$ & $\beta_{8}$ & 0.00005 & 0.020 & 0.002 \\
\hline FYM $\left(X_{9}\right)$ & $\beta_{10}$ & 0.005 & 0.007 & 0.69 \\
\hline Weedicides cost $\left(\mathrm{X}_{10}\right)$ & $\beta_{11}$ & $0.075 *$ & 0.042 & 1.78 \\
\hline Pesticides cost $\left(\mathrm{X}_{11}\right)$ & $\beta_{12}$ & $-0.239 *$ & 0.138 & -1.74 \\
\hline Irrigation cost $\left(\mathrm{X}_{12}\right)$ & $\beta_{13}$ & -0.106 & 0.101 & -1.05 \\
\hline $\begin{array}{l}\text { Dummy for soil type (1=Loamy, } \\
0=\text { otherwise) }\end{array}$ & $\eta_{1}$ & $0.080 * * *$ & 0.022 & 3.68 \\
\hline $\begin{array}{l}\text { Dummy for seed source }(1=\text { Self, } \\
0=\text { otherwise })\end{array}$ & $\eta_{2}$ & $-0.035 * *$ & 0.017 & -2.03 \\
\hline $\begin{array}{l}\text { Dummy for location ( } 1=\text { Rangpur, } \\
0=\text { otherwise) } \\
\text { Technical inefficiency model: }\end{array}$ & $\eta_{4}$ & $-0.939 * * *$ & 0.187 & -5.02 \\
\hline Constant & $\delta_{0}$ & 0.520 & 0.178 & 2.92 \\
\hline Operated land $\left(\mathrm{Z}_{1}\right)$ & $\delta_{1}$ & $-0.098 * * *$ & 0.0343 & 2.85 \\
\hline Farming experience $\left(\mathrm{Z}_{2}\right)$ & $\delta_{2}$ & -0.001 & 0.002 & -0.61 \\
\hline Farmers' education $\left(\mathrm{Z}_{3}\right)$ & $\delta_{3}$ & -0.008 & 0.007 & -1.19 \\
\hline Family size $\left(\mathrm{Z}_{4}\right)$ & $\delta_{4}$ & 0.012 & 0.011 & 1.07 \\
\hline $\begin{array}{l}\text { Dummy for extension linkage }(1=\text { Yes, } \\
0=\text { otherwise })\end{array}$ & $\delta_{5}$ & $-0.093 * * *$ & 0.036 & -2.56 \\
\hline $\begin{array}{l}\text { Dummy for potato training }(1=\text { Yes, } \\
0=\text { otherwise }) \\
\text { Variance parameters: }\end{array}$ & $\delta_{6}$ & -0.004 & 0.037 & -0.12 \\
\hline Sigma-squared & $\sigma^{2}$ & $0.007 * * *$ & 0.0009 & 7.18 \\
\hline Gamma & $\gamma$ & $1.000 * * *$ & 0.004 & 279.00 \\
\hline Log likelihood function & & & 90.30 & \\
\hline
\end{tabular}

$* * *, * *$ and $*$ indicate significant at $1 \%, 5 \%$ and $10 \%$ level of probability, respectively. Source: Field survey (2010) 
The estimated values of variance parameters $(\sigma$ and $\gamma)$ were large and significantly different from zero which indicated a good fit and correctness of the specified distributional assumption. The significant value of $\gamma$ also indicated that there were significant technical inefficiency effects in the production of potato.

Table 7. Frequency distribution of technical efficiency of potato producers in the study areas, 2010.

\begin{tabular}{l|l|l|l}
\hline \multirow{2}{*}{$\begin{array}{c}\text { Efficiency rates } \\
(\%)\end{array}$} & \multicolumn{3}{c}{ Frequency } \\
\cline { 2 - 4 } & \multicolumn{1}{|c}{ Rangpur } & \multicolumn{1}{c}{ Munshigonj } & \multicolumn{1}{c}{ All } \\
\hline Upto 70 & $4(13.3)$ & $3(10.0)$ & $7(11.7)$ \\
$71-80$ & $8(26.7)$ & $7(23.3)$ & $15(25.0)$ \\
$81-90$ & $14(46.7)$ & $15(50.0)$ & $29(48.3)$ \\
Above 90 & $4(13.3)$ & $5(16.7)$ & $9(15.0)$ \\
Mean & 85 & 87 & 86 \\
Maximum & 95 & 94 & 95 \\
Minimum & 65 & 60 & 60 \\
\hline
\end{tabular}

Figures in the parenthesis indicate percentage

The study revealed that about half of the respondents had technical efficiency level of 81-90. percent and only 15 percent had efficiency level of more than 90 percent (Table 7). On the other hand, 25 percent of the respondents had technical efficiency level of 71-80 percent. It was also observed that mean technical efficiency at Munshigonj was 0.87 , which was slightly higher than that of Rangpur (0.85). It implies that on average, the potato producers producing potato to about 87 and 85 percent of the potential frontier production levels, respectively. The mean technical efficiency of 86 percent also indicated that there existed 14 percent inefficiency and production could be increased by 14 percent with present level of technology.

\section{Conclusion}

Seed is a vital factor for agricultural production. Yield of potato was found higher with seeds from BADC compared to other sources. Farmers who used their own seeds obtained lower yield. This may be due to lack of knowledge regarding seed production and preservation by the farmers. The performance of self-produced and stored potato seeds are poor compared to the seeds from BADC. Supply of quality seeds to the farmers should be ensured by strengthening seed production and distribution system both in public and private sectors.

Most of the farmers did not use the recommended level of inputs especially fertilizers for potato production which might have a positive Contribution to 
yield. Therefore, farmers should be encouraged to use balanced dose of fertilizers and allocate their resources optimally and timely for increasing potato yield by maintaining soil health. The mean technical efficiency of 86 percent indicated that there existed 14 percent inefficiency and production could be increased by 14 percent with present level of technology by reallocating resources. Extension contact has a positive impact in increasing production of potato and farmers having frequent contact with extension personnel produced higher yield. Hence, farm level extension service should be strengthened further so that farmers' consciousness regarding improved production and management practices is ensured.

\section{References}

BBS. 1994. Yearbook of Agricultural Statistics of Bangladesh, 1993. Statistics Division, Ministry of Planning, Government of the People's Republic of Bangladesh, Dhaka, Bangladesh.

BBS. 2002. Yearbook of Agricultural Statistics of Bangladesh, 2001. Statistics Division, Ministry of Planning, Government of the People's Republic of Bangladesh, Dhaka, Bangladesh.

BBS. 2005. Yearbook of Agricultural Statistics of Bangladesh, 2004. Statistics Division, Ministry of Planning, Government of the People's Republic of Bangladesh, Dhaka, Bangladesh.

BBS. 2010. Statistical Yearbook of Bangladesh. Bangladesh Bureau of Statistics, Statistics Division, Ministry of Planning, Government of the People's Republic of Bangladesh, Dhaka, Bangladesh.

BBS. 2011. Yearbook of Agricultural Statistics of Bangladesh, 2011. Statistics Division, Ministry of Planning, Government of the People's Republic of Bangladesh, Dhaka, Bangladesh.

Beattie, B.R. and C.R. Taylor. 1985. The Economics of Production. Montana State University, John Wiley \& Sons, New York, USA.

Choudhury, D. A., M.A. Quayyum, M. A. Hossain and M. K. Hasan. 2006 (Edited). Project completion report SFFP II (1999-2006). On Farm Research Division. Bangladesh Agricultural Research Institute, Gazipur 1701. 383 Pp.

Coelli, T., S. Rahman and C. Thirtle. 2002. Technical, Allocative, Cost and Scale Efficiencies in Bangladesh Rice Cultivation: a Non-parametric Approach. J. Agril. Econ. 53 (3): 607-626.

Coelli, T. J. 1996. A guide to FORNTIER version 4.1: A Computer Program for Stochastic Frontier Production and Cost Function Estimation. CEPA working paper no 7/96, University of New England, Armidale, NSW-2351, Australia.

Heady, E. O. and J.L. Dillon. 1969. Agricultural Production Functions. Iowa State University Press, Ames, USA. 
Rahman, K. M. M. 2002. Measuring Efficiency of Producing Rice in Bangladesh: A Stochastic Frontier Analysis. Ph. D Thesis, Institute of Agricultural Policy and Marketing Research, Justus-Liebig University, Germany.

Rahman, S. 2003. Profit Efficiency among Bangladesh Rice Farmers. Food Policy 6 (2): 487-503.

Wang, J.; G.L. Cramer, and E.J. Wailes. 1996. Production efficiency of Chinese agriculture: evidence from rural household survey data. J. Agril. Econ., 15(1): 17-28. 
Appendix Table 1. Area, production and yield of potato in Bangladesh (1972-2010).

\begin{tabular}{l|c|c|c}
\hline Year & Area (ha) & Production (ton) & Yield (t/ha) \\
\hline $1971-72$ & 76260 & 740910 & 9.72 \\
$1972-73$ & 79575 & 746725 & 9.38 \\
$1973-74$ & 80080 & 718535 & 8.97 \\
$1974-75$ & 93890 & 866465 & 9.23 \\
$1975-76$ & 95960 & 888760 & 9.26 \\
$1976-77$ & 77400 & 723720 & 9.35 \\
$1977-78$ & 90085 & 849410 & 9.43 \\
$1978-79$ & 96900 & 894955 & 9.24 \\
$1979-80$ & 96510 & 902635 & 9.35 \\
$1980-81$ & 102155 & 983130 & 9.62 \\
$1981-82$ & 105980 & 1066755 & 10.07 \\
$1982-83$ & 110082 & 1131098 & 10.28 \\
$1983-84$ & 110200 & 1147686 & 10.41 \\
$1984-85$ & 111291 & 1159000 & 10.41 \\
$1985-86$ & 108458 & 1102000 & 10.16 \\
$1986-87$ & 106435 & 1069000 & 10.04 \\
$1987-88$ & 123432 & 1275000 & 10.33 \\
$1988-89$ & 111291 & 1089000 & 9.79 \\
$1989-90$ & 116552 & 1066000 & 9.15 \\
$1990-91$ & 123837 & 1237000 & 9.99 \\
$1991-92$ & 125860 & 1366000 & 10.85 \\
$1992-93$ & 129502 & 1384000 & 10.69 \\
$1993-94$ & 131121 & 1438000 & 10.97 \\
$1994-95$ & 131526 & 1468000 & 11.16 \\
$1995-96$ & 132335 & 1492000 & 11.27 \\
$1996-97$ & 133954 & 1508000 & 11.26 \\
$1997-98$ & 136382 & 1553000 & 11.39 \\
$1998-99$ & 244840 & 2762000 & 11.28 \\
$1999-00$ & 243221 & 2933000 & 12.06 \\
$2000-01$ & 248887 & 3216000 & 12.92 \\
$2001-02$ & 237556 & 2994000 & 12.60 \\
$2002-03$ & 245245 & 3386000 & 13.81 \\
$2003-04$ & 270741 & 3908000 & 14.43 \\
$2004-05$ & 326184 & 4856000 & 14.89 \\
$2005-06$ & 301093 & 4161000 & 13.82 \\
$2006-07$ & 345204 & 5167000 & 14.97 \\
$2007-08$ & 401862 & 6648000 & 16.54 \\
$2008-09$ & 395386 & 5268000 & 13.32 \\
$2009-10$ & 434562 & 7930240 & 18.25 \\
$2010-11$ & 460197 & 8326389 & 18.09 \\
\hline $5016:-259$ & &
\end{tabular}

Source: Rahman (1990), BBS (1998), BBS (2011). 